\title{
Comparison of the Dynamics between Coastal and Midshore Populations of Pinctada radiata (Leach, 1814) (Mollusca: Bivalvia) in the Gulf of Gabes, Tunisia
}

\author{
Abdelkarim Derbali ${ }^{1, *}\left(\mathbb{D}\right.$, Kandeel E. Kandeel ${ }^{2}$, Othman Jarboui ${ }^{1}$ \\ ${ }^{1}$ National Institute of Marine Sciences and Technologies of the Sea (INSTM), Sfax, Tunisia \\ ${ }^{2}$ Department of Zoology, Faculty of Science, Fayoum University, 63514 Fayoum, Egypt.
}

\section{Article History}

Received 28 May 2019

Accepted 25 June 2019

First Online 1 July 2019

\section{Corresponding Author}

Tel.: +21674497117

E-mail: derbali10@gmail.com

\section{Keywords}

Population dynamic

Growth

Mortality

Recruitment

Tunisia

\begin{abstract}
Pinctada radiata is the first lessepsian bivalve in the Mediterranean Sea where it has been progressively expanding westwards. This comparative study provides the first insight into the population dynamics of the species by investigating the population structure, growth, mortality, and exploitation status in the coastal zone (site A; 0-1 m) and midshore area (site $B ; 14 \mathrm{~m}$ depth). The results showed that the asymptotic shell length was smaller in the coastal zone $(L \infty=78.75 \mathrm{~mm})$ compared to that in the midshore station $(L \infty=105 \mathrm{~mm})$. Growth coefficient $(K)$ was higher in site $A(1.70 \mathrm{yr}$ $\left.{ }^{1}\right)$ than in site $B\left(0.66 \mathrm{yr}^{-1}\right)$. Growth performance index $\left(\Phi^{\prime}\right)$ values were almost similar (4.023 and 3.862) in both pearl oysters stocks. The theoretical maximum age $\left(T_{\max }\right)$ was smaller in site $A\left(2.66 \mathrm{yr}^{-1}\right)$ than in site $B\left(7.05 \mathrm{yr}^{-1}\right)$. Total mortality $(\mathrm{Z})$ was estimated by length-converted catch curve at 6.18 and $1.62 \mathrm{yr}-^{-1}$, fishing mortality $(F)$ at 4.43 and $0.78 \mathrm{yr}^{-1}$ and natural mortality (M) at 1.75 and $0.83 \mathrm{yr}^{-1}$ for site $\mathrm{A}$ and site $\mathrm{B}$, respectively. Recruitment was continuous and showed two major pulses in the two sampling sites.
\end{abstract}

\section{Introduction}

The marine mollusc Pinctada radiata (Leach, 1814) shows a widespread distribution occurring in almost all the seas of the tropical and in the subtropical regions (Al-Khayat \& Al-Ansi, 2008). It was considered as one of the three non-indigenous species from the family Pteriidae distributed along the Mediterranean Sea. The other two species are Pinctada margaritifera (Linné, 1758) and Electroma vexillum (Reeve, 1857) (Zenetos et al., 2010). $P$. radiata is stated as the first lessepsian bivalve species that arrived in the Mediterranean Sea via the Suez Canal (Monterosato, 1878). This indo-pacific bivalve has successfully spread throughout the Mediterranean Sea colonizing continuously new habitats in the eastern basin (Gokoglu, Gokoglu, \& Yerlikaya, 2006; Deidun, Gianni, Cilia, Lodola, \& Savini, 2014) and in the Adriatic Sea and Croatian coasts (Doğan \& Nerlović, 2008; Petović \& Mačić, 2017).

In Tunisia, $P$. radiata has not been exploited despite its importance as a major component of the benthic fauna. Bouchon- Brandely and Berthoule (1891) in the Gulf of Gabes made the first record of this species in Tunisia.

Previous surveys highlighted the high divergence between coastal and midshore pearl oyster populations in the Gulf of Gabes using discriminant tests (Derbali, 2011), which could be related to the environmental and ecological conditions of the two bathymetric zones. Such studies are important for investigating the 
dynamics of populations as a result to their potential adaptations since a variety of different conditions (e.g., climate, temperature, salinity, wave action, available substrate, species composition, species interactions, and food sources).

Geographical patterns of species abundance may provide insights into several questions in adaptation including: what type of growth performed by the pearl oyster in the harsh environmental conditions characterizing the coastal population or in offshore area subjected to the high cover vegetation and weak currents? Does pearl oyster have ability to response to climate changes? Thus, the species' adaptations to these factors can be studied by investigating the species population parameters. As such, the various pearl oyster population dynamics should be re-examined with consideration of the bathymetric distribution.

Despite its prevalence in the literature, no empirical work has rigorously investigated the pearl oysters' population dynamics. As commercial importance of $P$. radiata increases as a candidate species for Tunisian food and pearl production, research studies focusing on its population parameters will be of considerable necessity for future economic valorisation and sustainable management of this resource in Tunisian waters. In this context and considering the above mentioned scarce information on pearl oyster's dynamics, the present study is the first attempt to estimate the population structure, growth, mortality, and exploitation rates and recruitment pattern of coastal and midshore populations.

\section{Materials and Methods}

\section{Study Area}

Kerkennah Island is located in southern Tunisian waters $\left(10^{\circ} 58^{\prime}-11^{\circ} 20^{\prime} \mathrm{E}, 34^{\circ} 37^{\prime}-34^{\circ} 50^{\prime} \mathrm{N}\right)$. It is placed away from industrial activities or anthropogenic effluents. Both wide and shallow continental shelves are topographically regular. Specimens were sampled from two sampling sites, chosen with respect to depth and pearl oyster densities; the coastal zone (site A; 0-1 $\mathrm{m}$ depth) and the midshore area (site $B ; 14 \mathrm{~m}$ depth) (Figure 1). In site $A$, individuals were found on muddy sand covered in some areas by the marine seagrasses Cymodocea nodosa (Ascherson, 1870) and Zostera noltii (Hornemann, 1832). Specimens were encountered loose on the sandy bottom or attached to others mollusks. However, the midshore area is characterized by weak currents and large beds of Posidonia oceanica (Delile, 1813) reaching over 700 rhizomes $/ \mathrm{m}^{2}$. In some localities, the substratum was dominated by coral reefs and dead shells.

\section{Sampling Procedure}

In the two sampling sites, sampling was carried out from January to December 2010. Approximately 200 individuals were collected each month. At each site, large specimens were gathered by hand and the small ones were taken using a $2-\mathrm{mm}$ mesh size sieve in a swept area of $100 \mathrm{~m}^{2}$. Small individuals were found

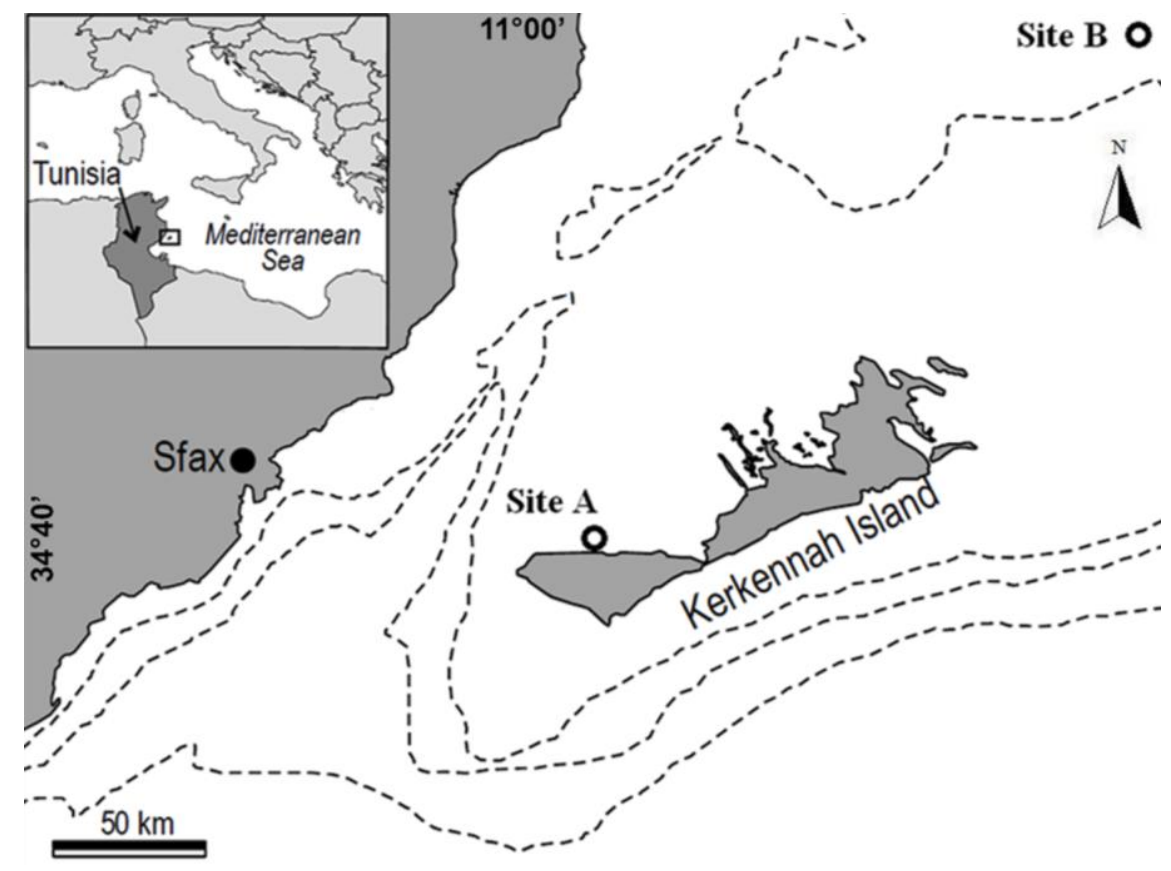

Figure 1. Geographical position of sampling sites of the pearl oyster Pinctada radiata in the Gulf of Gabes (Tunisia). 
attached by its byssus either to oysters' shells or to solid and vertical substrates. In the midshore area, sampling was conducted by scuba diving using a small boat.

Samples were carried to the laboratory where anterior-posterior shell length (SL) was measured with a digital caliper (precision of $0.01 \mathrm{~mm}$ ), while total wet weight (TW) was measured using a top-loading digital balance (precision of $0.001 \mathrm{~g}$ ).

\section{Data Analysis}

\section{Length-weight Relationships}

The relationship between total weight (TW, g) and anterior-posterior shell length ( $\mathrm{SL}, \mathrm{mm}$ ) was described by the following allometric equation:

$\log \mathrm{TW}=\log a+b \log \mathrm{SL}$

Where $\log a$ and $b$ are intercept (initial growth coefficient) and slope (relative growth rate of variables) of the linear regression line, respectively. The deviation of the $b$ value of the regression function from the isometric hypothetical value $(b=3)$ was analyzed by means of a Student's $t$-test. A significant deviation indicates a negative $(b<3)$ or positive $(b>3)$ allometric relationship.

Statistical analyses were carried out using MINITAB software (version 13, 2000). Statistical significance was considered when $\mathrm{P}<0.05$.

\section{Von Bertalanffy Growth Parameters}

Length-frequency data were analyzed using the FiSAT II software as explained in detail by Gayanilo, Sparre, and Pauly (2005). The asymptotic shell length $(\mathrm{L} \infty, \mathrm{mm})$ and the growth coefficient $\left(\mathrm{K}, \mathrm{yr}^{-1}\right)$ of the von Bertalanffy Growth Formula (VBGF) were estimated from the data by means of ELEFAN-I (Electronic Length Frequency Analysis; Pauly \& David, 1981; Pauly \& Morgan, 1987). The VBGF is defined by the equation:

$$
L_{t}=L_{\infty}\left[1-e^{-K\left(t-t_{0}\right)}\right]
$$

where $L_{t}=$ mean length at age $t, L_{\infty}=$ asymptotic shell length, $K=$ growth coefficient, $t=$ age, and $t_{0}$, the hypothetical age at which the length is zero (Pauly \& David, 1981), here $t_{0}=0$.

In addition, $L \infty$ and $K$ were used to calculate the growth performance index $\Phi^{\prime}$ (Pauly \& Munro, 1984) using the equation:

$\Phi^{\prime}=\log (K)+2 \log (L \infty)$

Growth performance index is a topic related closely to population dynamics of benthic macroinvertebrates. This index enables comparisons of the growth performances of specimens between our two sampling sites and with other populations of $P$. radiata. The inverse von Bertalanffy growth equation was used to find the lengths of $P$. radiata at various ages.

The theoretical maximum age $\left(T_{\max }\right)$ was calculated for each population by solving for $t$ in the von Bertalanffy equation by setting $L_{t}=L \infty$, using the following equation constructed by Michaelson and Neves (1995):

$$
\mathrm{T}_{\max }=\frac{\ln \mathrm{L}_{\infty}+\mathrm{Kt}_{\mathrm{o}}}{\mathrm{K}}
$$

\section{Mortality and Exploitation Rate}

Total mortality $\left(\mathrm{Z}, \mathrm{yr}^{-1}\right)$ was estimated by lengthconverted catch curve method (Pauly, 1990). FiSAT calculates $Z$ as well as the $95 \%$ confidence intervals surrounding $Z$ based on the goodness-of-fit of the regression.

Natural mortality rate $\left(\mathrm{M}, \mathrm{yr}^{-1}\right)$ was estimated using the empirical relationship of Pauly (1980):

$\log _{10} M=-0.0066-0.279 \log _{10} L \infty+0.6543 \log _{10} K$ $+0.4634 \log _{10} \mathrm{~T}$

Once $Z$ and $M$ were obtained, then fishing mortality $\left(F, \mathrm{yr}^{-1}\right)$ was estimated using the relationship: $\mathrm{F}=\mathrm{Z}-\mathrm{M}$.

The exploitation rate (E) was obtained with the relationship proposed by Gulland (1971):

$$
E=F / Z=F /(M+F)
$$

\section{Recruitment Pattern}

The routine in FiSAT reconstructs the recruitment pulses from a time series of length-frequency data to determine the number of pulses per year and the relative strength of each pulse, using the VBGF parameters (Moreau \& Cuende, 1991). Normal distribution of the recruitment pattern (\%) was determined by NORMSEP (Pauly \& Caddy, 1985) in FiSAT.

\section{Results}

\section{Length-weight Relationships}

Relationships between logarithmically transformed data of total wet weight (TW, g) and shell length $(\mathrm{SL}, \mathrm{mm}$ ) of the pearl oyster $P$. radiata collected from sites A and B are shown in Table 1. At both sites, the slope $(b)$ of the linear regression significantly deviated from $3(P<0.05)$ indicating negative allometric growth pattern.

\section{Population Structure}

Overall, 2422 and 2360 individuals of $P$. radiata were measured and their population structure studied for site $A$ and site $B$, respectively (Figure 2). The shell length ranged between $6.20-79.00$ and $7.80-95.15$ $\mathrm{mm}$ for sites $A$ and $B$, respectively (Table 2 ). The majority of pearl oyster populations were in size classes $35-55$ and $45-70 \mathrm{~mm}$ which represented 75.76 and $67.29 \%$ of the total samples collected from the two sites, 
Table 1. Regression parameters (log $a$ and $b$ ) of shell length (SL, $\mathrm{mm}$ ) and total weight (TW, g) relationships of Pinctada radiata collected from the coastal (site A) and the midshore (site B) areas in the Gulf of Gabes, Tunisia. Values of Student $t$ - test $(t)$ and level of significance of the deviation from the isometric value of the slope $(\theta=3)(p)$, coefficient of determination $\left(r^{2}\right), \mathrm{SL}$ range, TW range and number of animals examined $(\mathrm{N})$ are also given, S.D. = standard deviation

\begin{tabular}{lllllllll}
\hline \multicolumn{10}{c}{ Length-Weight relationship } \\
\hline Sites & Log $a \pm$ S.D. & $b \pm$ S.D. & $t$ & $p$ & $r^{2}$ & SL range & TW range & $N$ \\
Site A & $-2.70 \pm 0.13$ & $2.27 \pm 0.08$ & 9.13 & $<0.05$ & 0.798 & $23.5-63.7$ & $1.58-26.63$ & 195 \\
Site B & $-3.48 \pm 0.07$ & $2.75 \pm 0.04$ & 6.25 & $<0.05$ & 0.956 & $16.45-101$ & $0.81-121.5$ & 217 \\
\hline
\end{tabular}

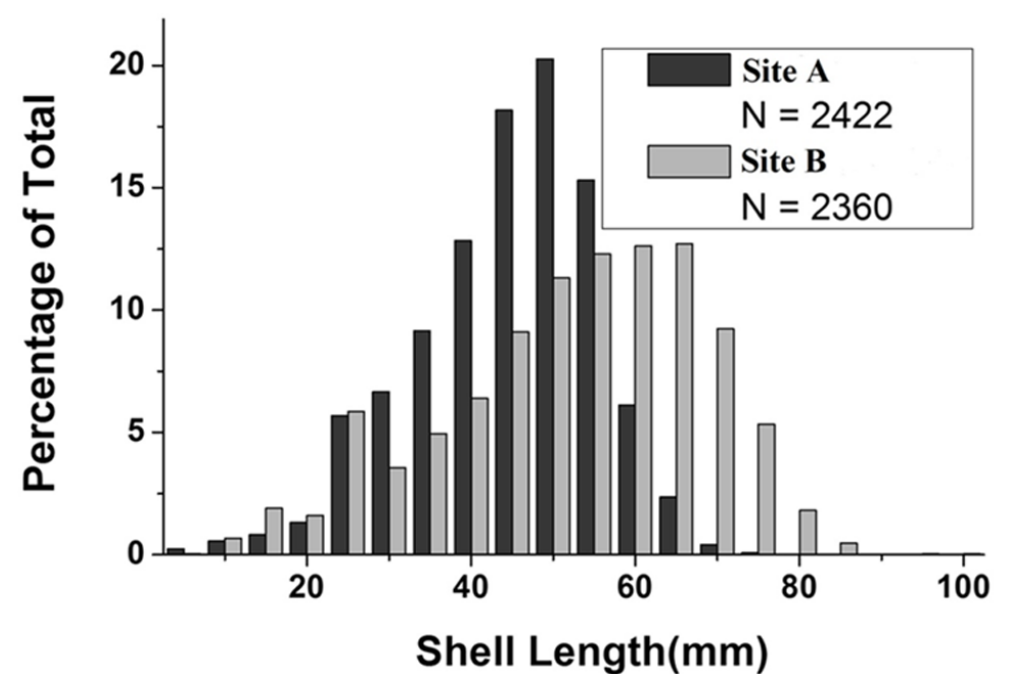

Figure 2. Variations in the percentage occurrence of the different size classes of Pinctada radiata collected from site A and site $B$ throughout the study period. $\mathrm{N}=$ number of oysters examined.

Table 2. Population parameters of Pinctada radiata collected from coastal and midshore populations in the Gulf of Gabes, southern Tunisia

\begin{tabular}{lll}
\hline Population parameters & Coastal population & Midshore population \\
\hline Asymptotic length $(\mathrm{L} \infty)$ in mm & 78.75 & 105.00 \\
Growth co-efficient $(\mathrm{K}) \mathrm{yr}^{-1}$ & 1.70 & 0.66 \\
Growth performance index ( $\Phi)$ & 4.023 & 3.862 \\
The theoretical maximum age $\left(\mathrm{T}_{\max }\right) \mathrm{yr}^{-1}$ & 2.66 & 7.05 \\
Natural mortality $(\mathrm{M}) \mathrm{yr}^{-1}$ & 1.752 & 0.836 \\
Fishing mortality $(\mathrm{F}) \mathrm{yr}^{-1}$ & 4.43 & 0.78 \\
Total mortality $(\mathrm{Z}) \mathrm{yr}^{-1}$ & 6.18 & 1.62 \\
Exploitation rate $(\mathrm{E})$ & 0.72 & 0.48 \\
Shell length $(\mathrm{SL})$ range $(\mathrm{mm})$ & $6.20-79.00$ & $7.80-101.00$ \\
Sample number $(\mathrm{N})$ & 2422 & 2360 \\
\hline
\end{tabular}

respectively. Large individuals (> $70.00 \mathrm{~mm}$ ) constituted 0.49 and $16.95 \%$ of total samples collected from site $A$ and site $B$, respectively.

\section{Growth Parameters}

Estimated asymptotic length $(\mathrm{L} \infty)$ and growth coefficient (K) of the von Bertalanffy Growth Formula (VBGF) by ELEFAN-I were $78.75 \mathrm{~mm}$ and $1.700 \mathrm{yr}^{-1}$ and
$105.00 \mathrm{~mm}$ and $0.660 \mathrm{yr}^{-1}$ for pearl oysters collected from site $A$ and site $B$, respectively (Figures 3-4 and Table 2). Figures 3 and 4 show length frequency distributions and the superimposed growth curves estimated by ELEFAN-I for $P$. radiata collected from site $A$ and site $B$, respectively. Growth performance index calculated with the parameter estimates from ELEFAN-I (Ф) was 4.023 and 3.862 in site $A$ and site $B$, respectively (Table 2). 


\section{Age and Growth}

The sizes attained by the coastal pearl oyster population were 64 and $76 \mathrm{~mm}$ at the end of $1^{\text {st }}$ and $2^{\text {nd }}$ years of age, respectively (Figure 5). For the midshore population, the sizes attained were $50.71,76.96,90.51$, 97.54 , and $101.12 \mathrm{~mm}$ at the end of $1^{\text {st }}, 2^{\text {nd }}, 3^{\text {rd }}, 4^{\text {th }}$ and $5^{\text {th }}$ years of age, respectively (Figure 5 ). Therefore, the average growth rate of $P$. radiata through the $2^{\text {nd }}$ year of life was shown as similar values; 76.13 and $76.96 \mathrm{~mm}$. $\mathrm{yr}^{-1}$ for site $A$ and site $B$, respectively. However, the theoretical maximum age $\left(T_{\max }\right)$ was higher in site $B\left(T_{\max }\right.$ $\left.=7.05 \mathrm{yr}^{-1}\right)$ than in site $A\left(T_{\max }=2.66 \mathrm{yr}^{-1}\right)$ (Table 2).

\section{Mortality and Exploitation Rate}

Length-converted catch curve analysis allowed to estimate total mortality (Z) for $P$. radiata $6.18 \mathrm{yr}^{-1}$ for site $A$ and $1.62 \mathrm{yr}^{-1}$ for site $B$ (Table 2). The linearized catch curves utilized in the estimation of $Z$ are presented in Figures 6 and 7 for the two sites, respectively. The darkened circles represented the points used in calculating $Z$ via linear regression analysis. For the coastal population, the intercept $(a)$ and slope $(b) \pm S$.D. of the regression line on the selected data points were $11.69 \pm 1.09$ and $-6.18 \pm 0.78$, respectively. For the midshore population, the intercept $(a)$ and slope $(b) \pm$

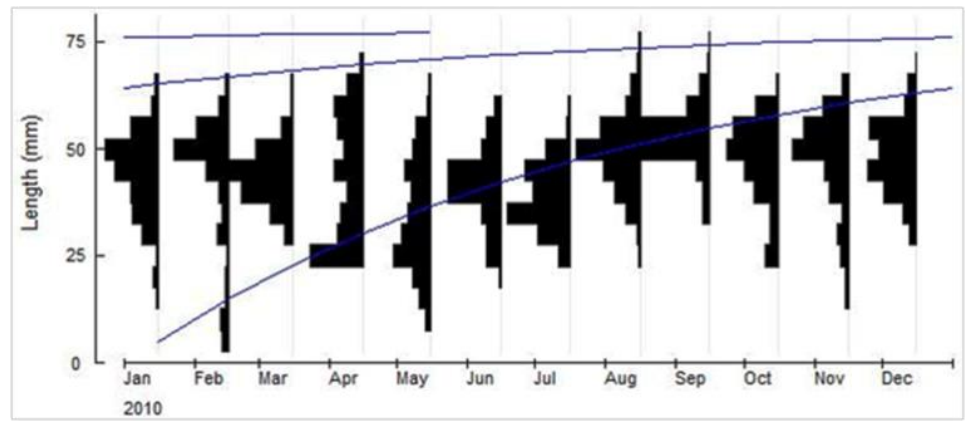

Figure 3. Length-frequency plot of Pinctada radiata samples taken from site A with superimposed growth curves estimated by ELEFAN $1\left(\mathrm{~L} \infty=78.75 \mathrm{~mm}\right.$ and $\left.\mathrm{K}=1.700 \mathrm{yr}^{-1}\right)$.

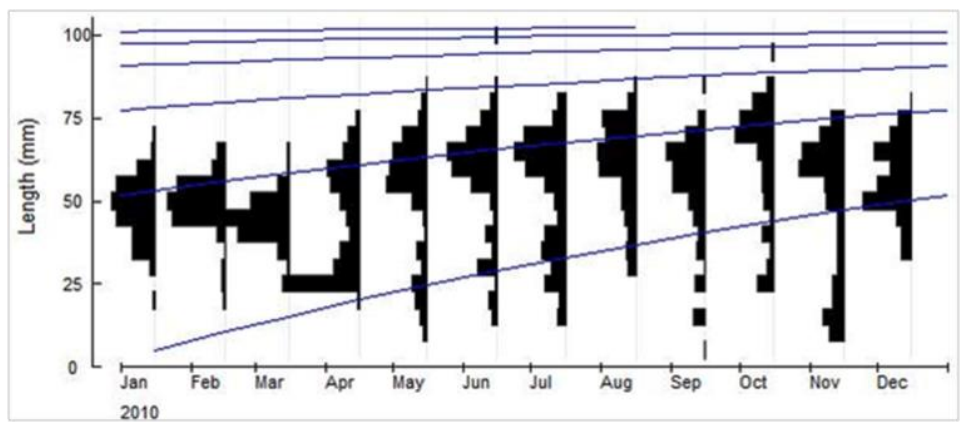

Figure 4. Length-frequency plot of Pinctada radiata samples taken from site B with superimposed growth curves estimated by ELEFAN $1\left(L \infty=105.00 \mathrm{~mm}\right.$ and $\left.\mathrm{K}=0.660 \mathrm{yr}^{-1}\right)$.

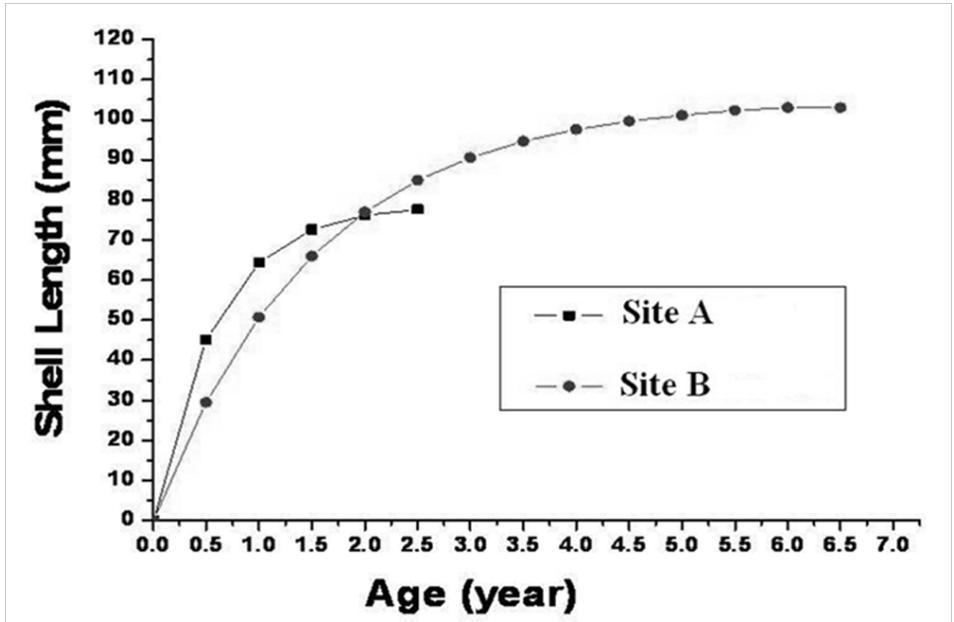

Figure 5. von Bertalanffy growth curves in terms of size at age based on the growth parameters estimated from ELEFAN-I for Pinctada radiata collected from site $\mathrm{A}$ and site $\mathrm{B}$. 


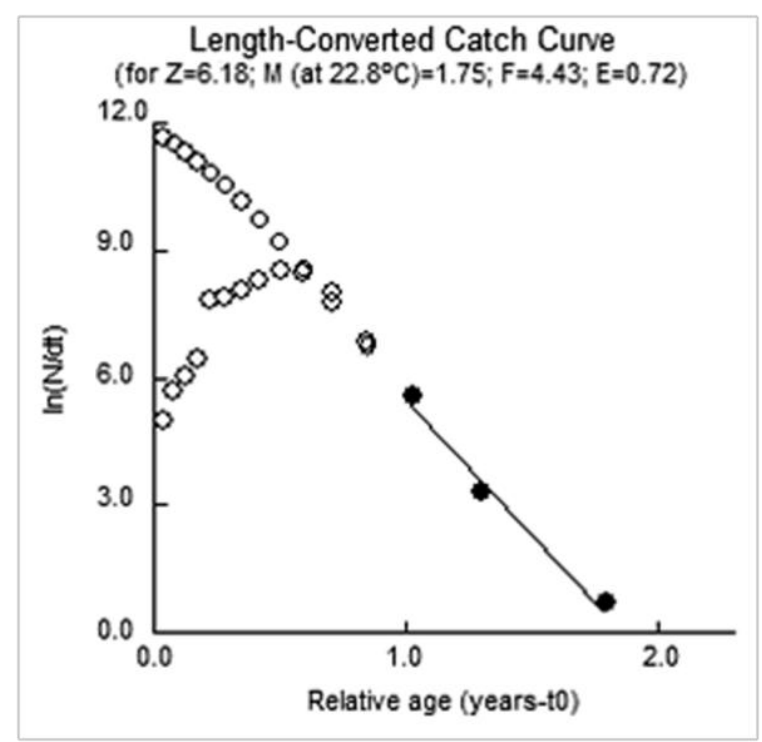

Figure 6. Length converted catch curve of Pinctada radiata collected from site A.

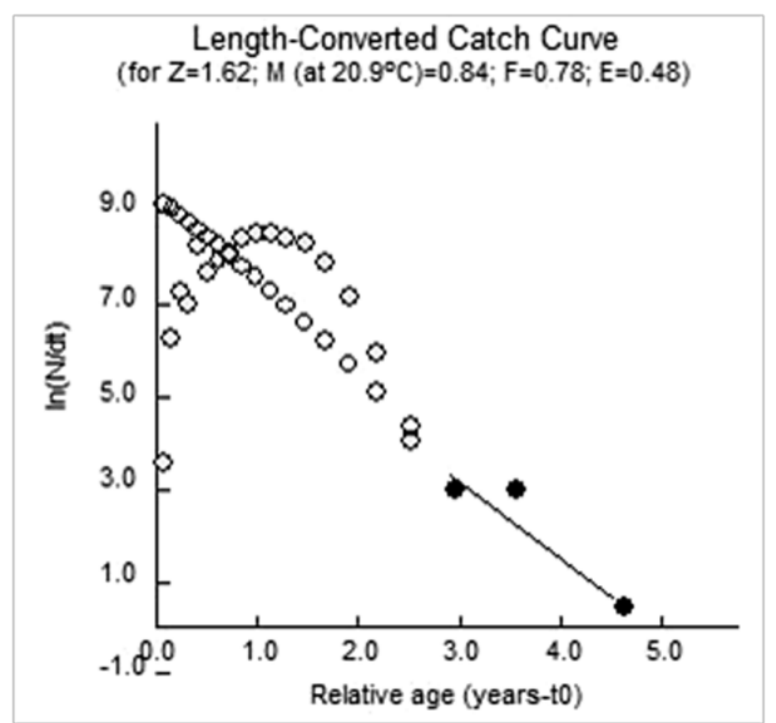

Figure 7. Length converted catch curve of Pinctada radiata collected from site B.

S.D. of the regression line were $7.17 \pm 2.39$ and $-1.62 \pm$ 0.63 , respectively.

Estimated value of natural mortality (M) from Pauly's empirical formula was higher $\left(1.75 \mathrm{yr}^{-1}\right)$ for site A than site $B\left(0.84 \mathrm{yr}^{-1}\right)$. Fishing mortality $(F)$ was estimated to be 4.43 and $0.78 \mathrm{yr}^{-1}$ for the two sites, respectively (Table 2 ). The rate of exploitation (E) was estimated at 0.72 for site $A$ and 0.48 for site $B$ (Table 2).

\section{Recruitment Pattern}

The recruitment patterns (\%) generated by FiSAT for $P$. radiata for the two sites were continuous throughout the year with two major pulses. For site $A$, the relative strength of the pulse was 6.07 and $27.70 \%$ recruitment in February and August, respectively (Figure 8). For site $B$, the relative strength of the pulses were
13.64 and $13.94 \%$ recruitment in April and August, respectively (Figure 9).

\section{Discussion}

The present study provided new information about the population structure, growth, mortality, and exploitation rates and recruitment pattern of pearl oyster populations at two different depth zones in Kerkennah Island (Gulf of Gabes). Mean shell length seems to be a good indicator for biomass, production and stock assessment estimates as already reported in P. radiata (Derbali, Jarboui, Ghorbel, \& Dhieb, 2009; Deidun et al., 2014) and in other bivalves (Kandeel, 2008; Zeinalipour, Hasanzadeh Kiabi, Reza Shokri, \& Ashja Ardalan, 2014; Kandeel, Mohammed, Mostafa, \& Abd-Alla, 2017). In this study, we can report that, as the 


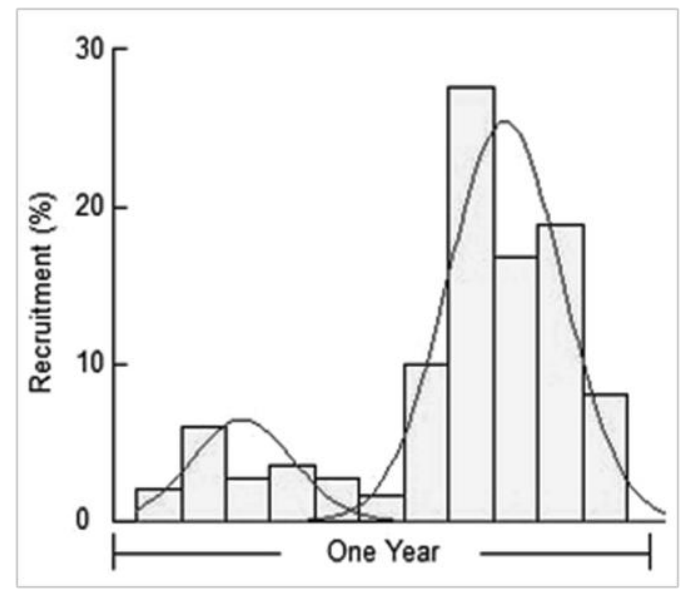

Figure 8. Predicted recruitment pattern of Pinctada radiata population in site A.

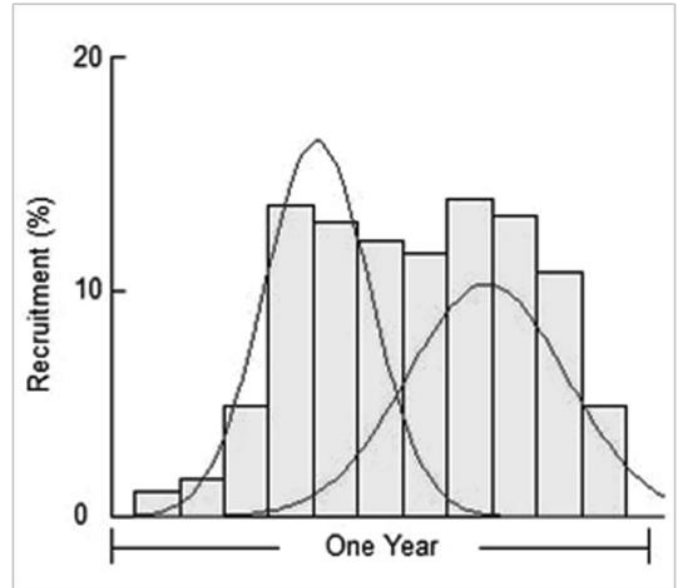

Figure 9. Predicted recruitment pattern of Pinctada radiata population in site B.

pearl oyster grows, its weight increases at a slower rate than its length in sites $A$ and $B$. These variations in the morphometric relationships between localities can be related to environmental factors such as depth and sediment type. For example, Bellaaj-Zouari, Dkhili, Gharsalli, Derbali, and Aloui-Bejaoui (2012) showed that low tides marks might affect the morphology of $P$. radiata individuals.

The positive correlation between size and depth has previously been reported in the study area (Derbali, 2011). $P$. radiata was encountered from intertidal zone to $40 \mathrm{~m}$ depth, with a highest population density (145 inds $/ \mathrm{m}^{2}$ ) recorded at depth range of 2-20 m. Sexton, Mclntyre, Angert, and Rice (2009) showed that physical and ecological factors controlling distributional ranges of the species have received heightened attention due to anticipated climate change and increased biological invasions.

Morphological differences from different environments have previously been reported for bivalves (e.g. Yoshino, Katano, Hayami, Hamada, \& Kobayashi, 2013; Diederich et al., 2015). As such, pearl oysters may have a mechanism that compensates for reduced feeding time, this could potentially limit their densities, especially if slower growth delays a potential escape in size from mortality in the intertidal zone (Hunt \& Scheibling, 1997). Though other filter feeders may periodically stop feeding while submerged (e.g., Cranford, Ward, \& Shumway, 2011), it is unknown what would cause $P$. radiata to perform in this way while under water in ideal conditions (e.g., normal salinity, oxygen, and temperature, and no predators). It seems that the maximum size (95 $\mathrm{mm}$ ), recorded in deeper waters site, is larger than that observed by Seurat (1929) (85 mm) in El Bibane Lagoon and Tlig-Zouari (1993) in the Kerkennah Islands (74 mm). This maximum size is also larger than that recorded by Yassien (1998) and Yassien, Abd EL-Razek, and Kilada (2000) in the Red Sea (93.2 $\mathrm{mm}$ ) and eastern Mediterranean Sea (64 mm), respectively. Nevertheless, it is smaller than that recorded by Tlig-Zouari, Rabahoui, Irathni, and Ben Hassine (2009) along the northern and eastern Tunisian coasts (100.5 mm).

The asymptotic shell length $(L \infty)$ derived from the coastal population was smaller than that of the midshore population. Differences in populations' 
distribution and in growth have been assumed in discussions of evolutionary hypotheses including theoretical studies of the species life-history strategies in their habitat. Differences in the growth parameters of pearl oyster in the present study and other studies (Table 3) might be due to differences in the ecosystems investigated and the responses of species to environmental gradients. Saeedi, Ardalan, Kamrani, and Kiabi (2010) have suggested several key factors affecting growth at the local scale in bivalves inhabiting the northern Persian Gulf including individual's difference, climate, latitude, and longitude.

The negative correlation between $L_{\infty}$ and $K$ invalidates comparison based on individual parameters (Pauly \& Munro, 1984). As a result, comparison of the growth performance of population of bivalves is better fitted by the growth index phi prime $\left(\Phi^{\prime}\right)$. This criterion was used to characterize not only similar species (Pauly \& Munro, 1984), but also related species as in the case of scallops (Del Norte, 1988). On comparison, Mohammed and Yassien (2003) estimated $L \infty$ for $P$. radiata in Qatari waters as $107.0 \mathrm{~mm}$ and $\mathrm{K}$ as $0.25 \mathrm{y}^{-1}$. Yassien (1998) calculated $\mathrm{L} \infty=95.74 \mathrm{~mm}$ and $\mathrm{K}=0.41 \mathrm{y}$ ${ }^{1}$ for the same species in the Red Sea. Yassien et al. (2000) estimated Lo as $69.18 \mathrm{~mm}$, and $\mathrm{K}$ as $0.56 \mathrm{y}^{-1}$ for $P$. radiata in the eastern Mediterranean. These differences can be explained by the different methods applied for age determination. Also, it can be explained by the different survival strategies and ecological factors present at different latitudes.

The data presented here confirm that $P$. radiata is a fast-growing species. On comparison, obtained values are higher than that reported by Mohammed (1994), Yassien (1998), Yassien et al. (2000), and Mohammed and Yassien (2003). On the whole, nonlinear growth functions such as the VBGF are difficult to compare, and some authors (e.g., Herrmann, 2009) have demonstrated the suitability of composite indices of overall growth performance for comparisons for various clam species. Both coastal and midshore populations from study area exhibited higher growth performance. It can be assumed that food availability is a principal factor affecting growth and aspects of population dynamics such as production, reproduction, recruitment and mortality.
Total mortality rate of $P$. radiata at the coastal site was higher than at the midshore site, and fishing mortality for midshore pearl oysters was lower than that for coastal ones. We can speculate that the higher fishing mortality at the coastal zone might be attributed to the commercial harvesting of the shellfish, Venerupis decussata (Linnaeus, 1758) and Hexaplex trunculus (Linnaeus, 1758) and to the other different fishing activities. In the same way, natural mortality reported for coastal pearl oysters was higher than that estimated for the midshore area. This might be attributed to the anthropogenic activities (e.g. habitat modification and habitat degradation). Earlier studies have shown that commercial harvesting can reduce the fitness of bivalves on intertidal areas leading to their higher mortality (Robinson \& Richardson, 1998).

Salinity may be the main factor affecting pearl oyster abundance in the inshore area. It reached high values in the study area ranging between $31.8-48.6 \%$ and $30-48 \%$ at site $A$ and site B, respectively (Derbali, 2011). For other bivalve species, Boyden and Russel (1972) stated that maximum age was reduced within hypersaline environments. On the whole, the coastal zone is associated with reduced performance (i.e., feeding rate) in some marine invertebrates (e.g., Miller, Harley, \& Denny, 2009). The pattern of size distribution (midshore $>$ coastal) in $P$. radiata suggests that coastal individuals could be stressed in relatively poor physiological condition compared to midshore individuals. Similar events were reported for the gastropod species Crepipatella peruviana (Lamarck, 1822 ) readily found both intertidally and subtidally in Chile waters (Diederich et al., 2015). Coastal P. radiata population may of course have physiological adaptations for maximizing energy gain that we did not quantify in this study.

Recruitment of $P$. radiata in the two sites was yearround and exhibited two major pulses. This pattern of recruitment is typical for tropical bivalves, which are fast-growing and short-lived species (Del Norte, 1988; Mohammed \& Yassien, 2003; Del Norte-Campos, 2004; Kandeel et al., 2017). However, recruitment pulses were not found to be correlated with the spawning pattern in the study areas, as previous findings have demonstrated that this species displayed a clearly defined annual

Table 3. Values of von Bertalanffy growth parameters ( $K$ and $L \infty)$ and growth performance indices ( $\left.\phi^{\prime}\right)$ of Pinctada radiata in different localities; $\phi=\log K+2 \log L \infty$

\begin{tabular}{lllll}
\hline Locations & $K y r^{-1}$ & $L \infty(\mathrm{mm})$ & $\phi^{\prime}$ & References \\
\hline Coastal population, Gulf of Gabes, Tunisia & 1.70 & 78.75 & 4.023 & Present study \\
Midshore population, Gulf of Gabes, Tunisia & 0.66 & 105.00 & 3.862 & Present study \\
Qatari waters, Arabian Gulf & 0.34 & 132.18 & 1.77 & Mohammed (1994) \\
Qatars waters, Arabian Gulf & 0.25 & 107.00 & 1.456 & Mohammed \& Yassien (2003) \\
Eastern Mediterranean, Egypt & 0.56 & 69.2 & 1.428 & Yassien et al. (2000) \\
Red Sea, Egypt & 0.41 & 102.3 & 1.637 & Yassien (1998) \\
\hline
\end{tabular}


reproductive cycle with two peaks occurring in summer and autumn (Derbali, 2011).

Finally, the peal oyster $P$. radiata is an extremely successful invasive species in Tunisian waters due to its ability to perform well in the not preferred living conditions that characterize the coastal zone. Our findings focused on the pearl oyster populations' dynamics in two different ecological sites could be a crucial baseline to assess their stock. The data may help to determine future quantitative changes indicating trends in Tunisian waters that are exposed to various factors of environmental conditions and human activities. Further studies are needed to explore the association between spawning and recruitment for $P$. radiata with environmental variables. Also, genetic investigations are required to understand the relative abilities to invade new areas.

\section{Acknowledgements}

This work was undertaken within the framework of research activities in the Laboratory of Fisheries Sciences of the National Institute of Marine Sciences and Technologies (INSTM). Special thanks to the technical and supporting staff for their practical assistance in sampling and laboratory analysis. We wish to thank anonymous reviewers for their suggestions and constructive comments, which helped to improve the quality of this manuscript.

\section{References}

Al-Khayat J.A., \& Al-Ansi M.A. (2008). Ecological features of oyster beds distribution in Qatari waters, Arabian Gulf. Asian Journal of Science Research, 1, 544-561. https://dx.doi.org/10.3923/ajsr.2008.544.561

Bellaaj-Zouari, A., Dkhili, S, Gharsalli, R., Derbali, A., \& AlouiBejaoui, N. (2012). Shell morphology and relative growth variability of the invasive pearl oyster Pinctada radiata in coastal Tunisia. Journal of the Marine Biological Association UK, 92, 553-563 https://dx.doi.org/10.1017/S0025315411001925

Bouchon-Brandely, M., \& Berthoule, A. (1891). Les pêches maritimes en Algérie et en Tunisie (Rapport au Ministère de la Marine). Paris., $118 \mathrm{pp}$.

Boyden, C.R., \& Russel, P.J.C. (1972). The distribution and habitat range of the brackish water cockle (Cardium (Cerastoderma glaucum) in the British Isles. Journal of Animal Ecology, 41, 719-734.

http://www.marlin.ac.uk/speciesbibliography.php?spec ies $=2924$

Cranford, P.J., Ward, J.E., \& Shumway, S.E. (2011). Bivalve filter feeding: variability and limits to the aquaculture biofilter. In Shumway S.E. (Eds.), Shellfish aquaculture and the environment. Wiley-Blackwell, Chichester, 44 pp.

Deidun, A., Gianni, F., Cilia, D.P., Lodola, A., \& Savini, D. (2014). Morphometric analyses of a Pinctada radiata (Leach, 1814) (Bivalvia: Pteriidae) population in the Maltese Islands. Journal of Black Sea / Mediterranean Environment, 20 (1): 1-12. http://blackmeditjournal.org/wp-content/uploads/112-Vol20No1-Deidun.pdf

Diederich, C.M, Chaparro, O.R, Mardones-Toledo, D.A., Garrido, G.P., Montory, J.A., \& Pechenik, J.A. (2015). Differences in feeding adaptations in intertidal and subtidal suspension-feeding gastropods: studies on Crepidula fornicate and Crepipatella peruviana. Marine Biology, 162, 1047-1059.

https://dx.doi.org/10.1007/s00227-015-2648-2

Del Norte, A.G.C. (1988). Aspects of the growth, recruitment, mortality and reproduction of the Asian Moon Scallop, Amusium pleuronectes (Linné) in the Lingayen Gulf, Philippines. Ophelia, 29, 153-168.

http://dx.doi.org/10.1080/00785326.1988.10430826

Del Norte-Campos, A.G.C. (2004). Some aspects of the population biology of the sunset elongate clam Garielongata (Lamarck 1818) (Mollusca, Pelecypoda: Psammobiidae) from the Banate Bay area, West Central Philippines. Asian Fisheries Science, 17, 299-312. https://www.asianfisheriessociety.org/publication/dow nloadfile. php?id $=598 \&$ file $=$ YOdSbUx6QXdNamszTnpRd0 1ERXPOVFU1TURFMU1UQXVjR1Jt

Derbali, A. (2011). Biologie, abondance et cartographie de deux espèces de Bivalves : I'huître perlière Pinctada radiata et la coque glauque Cerastoderma glaucum dans le golfe de Gabès. PhD Thesis, University of Sfax, Tunisia, $169 \mathrm{pp}$.

Derbali, A., Jarboui, O., \& Ghorbel, M. (2011). Distribution, abundance and population structure of Pinctada radiata (Mollusca: Bivalvia) in southern Tunisian waters (Central Mediterranean). Cahiers de Biologie Marine, 52, 23-31.

Derbali, A., Jarboui, O., Ghorbel, M., \& Dhieb, K. (2009). Reproductive biology of the pearl oyster, Pinctada radiata (Mollusca: Pteriidae), in northern Kerkennah Island (Gulf of Gabes). Cahiers de Biologie Marine, 50, 215-222. https://dx.doi.org/10.21411/CBM.A.FOF1EF1F https://dx.doi.org/10.21411/CBM.A.1F62F460

Doğan, A., \& Nerlović, V. (2008). On the occurrence of Pinctada radiata (Mollusca: Bivalvia: Pteriidae), an alien species in Croatian waters. Acta Adriatica, 49 (2), 155-158. http://jadran.izor.hr/acta/pdf/49_2_pdf/49_2_6.pdf

Gayanilo, F.C. Jr, Sparre, P. \& Pauly, D. 2005. FAO-ICLARM stock assessment tools II (FiSAT)-revised version, User's guide, FAO, Rome. http://www.fao.org/3/a-y5997e/

Gokoglu, N., Gokoglu, M., \& Yerlikaya, P. (2006). Seasonal variations in proximate and elemental composition of pearl oyster (Pinctada radiata, Leach, 1814). Journal of the Science of Food and Agriculture, 86, 2161-2165. https://dx.doi.org/10.1002/jsfa.2591

Gulland, J.A. (1971). Fish Resources of the Ocean. Fishing New Books, London. $255 \mathrm{pp}$. https://dx.doi.org/10.1080/00785326.1988.10430826

Herrmann, M. (2009). Population structure, growth and production of the surf clam Donax hanleyanus (Bivalvia: Donacidae) from northern Argentinean beaches. PANGAEA, https://dx.doi.org/10.1594/PANGAEA.690503

Hunt, H.L., \& Scheibling, R.E. (1997). Role of early postsettlement mortality in recruitment of benthic marine invertebrates. Marine Ecology Progress Series, 155, 269301. https://dx.doi.org/10.3354/meps155269

Kandeel, K.E. (2008). Length-weight relationships and monthly variations in body weights and condition indices of two clam's species; Venerupies aurea and Tapes decussata in Lake Timsah, Egypt. Catrina, 3 (1), 111-124. 
http://cat.journals.ekb.eg/article_18520_c8aa4e55082f 286b44ed3ebea85f826a.pdf

Kandeel, K. E., Mohammed, S.Z., Mostafa, A.M., \& Abd-Alla, M.E. (2017). Population Dynamics of the Cockle Cerastoderma glaucum: A comparison between Lake Qarun and Lake Timsah, Egypt. Turkish Journal of Fisheries and Aquatic Sciences, 17, 945-958. https://dx.doi.org/10.4194/1303-2712-v17_5_10.

Michaelson, D.L., \& Neves, R.J. (1995). Life history and habitat of the endangered dwarf wedgemussel Alasmidonta heterodon (Bivalvia: Unionidae. Journal of the North American Benthological Society, 14, 324-340. https://www.jstor.org/stable/1467784

Miller, L.P., Harley, C.D.G., \& Denny, M.W. (2009). The role of temperature and desiccation stress in limiting the localscale distribution of the owl limpet, Lottia gigantea. Functional Ecology, 23,756-767. https://dx.doi.org/10.1111/j.1365-2435.2009.01567.x

Mohammed, S.Z. (1994). Pearl oyster project. Phase 1: Survey and ecological studies on Qatari pearl oyster beds. Pilot investigation report. SARC, Qatar. $91 \mathrm{pp}$.

Mohammed, S.Z., \& Yassien, M.H. (2003). Population parameters of the pearl oyster Pinctada radiata (Leach) in Qatari waters, Arabian Gulf. Turkish Journal of Zoology, 27, 339-343.

http://journals.tubitak.gov.tr/zoology/issues/zoo-0327-4/zoo-27-4-10-0207-7.pdf

Monterosato T.A. 1878. Enumerazione e sinonimia delle conchiglie Mediterranee. Giornale di scienze naturali ed economiche di Palermo, 13, 61-113.

Moreau, J., \& Cuende, F.X. (1991). On improving the resolution of the recruitment pat-terns of fishes. ICLARM Fishbyte, 9, 45-46. http://pubs.iclarm.net/Naga/FB_3131.pdf

Pauly, D. (1980). On the interrelationships between natural mortality, growth parameters and mean environmental temperature in 175 fish stocks. Journal du Conseil/Conseil Permanent International pour I'Exploration de la Mer, 39, 175-192.

http://innri.unuftp.is/pauly/On\%20the\%20interrelation ships\%20betwe.pdf

Pauly, D. (1990). Length-converted catch curves and the seasonal growth of fishes. ICLARM Fishbyte, 8, 33-38. http://pubs.iclarm.net/Naga/FB_1365.pdf

Pauly, D., \& Caddy, J.F. (1985). A modification of Bhattacharya's method for the analysis of mixtures of normal distributions. FAO Fisheries Circular 781, $16 \mathrm{pp}$.

Pauly, D., \& David, N. (1981). ELEFAN-1, a BASIC program for the objective extraction of growth parameters from length frequency data. Berichte der Deutshen Wissenschaftlichen Kommission fur Meeresforschung, 28, 205-211.

http://legacy.seaaroundus.s3.amazonaws.com/doc/Res earcher+Publications/dpauly/PDF/1981/Journal+Article s/ELEFAN_I_BasicProgramObjectiveExtractionGrowthPa rametersLeng.pdf

Pauly, D., \& Morgan, G.R. (1987). Length-based methods in fisheries research. ICLARM Conference Proceedings, 13: $468 \mathrm{pp}$.

Pauly, D., \& Munro, J.L. 1984. Once more on the comparison of growth in fish and invertebrate. Fishbyte, 2: $21 \mathrm{pp}$. http://pubs.iclarm.net/Naga/na_1951.pdf

Petović, S., \& Mačić, V. (2017). New data on Pinctada radiata (Leach, 1814) (Bivalvia: Pteriidae) in the Adriatic Sea. Acta Adriatica, 58(2), $359 \quad-364$. http://jadran.izor.hr/acta/pdf/58_2_pdf/58_2_14.pdf
Robinson, R.F., \& Richardson, C.A. (1998). The direct and indirect effects of suction dredging on a razor clam Ensis arcuatus population. ICES Journal of Marine Science, 55, 970-977.

http://icesjms.oxfordjournals.org/content/55/5/970.ful I.pdf

Saeedi, H, Ardalan, A.A, Kamrani, E., \& Kiabi, B.H. (2010). Reproduction, growth and production of Amiantis umbonella (Bivalvia: Veneridae) on northern coast of the Persian Gulf, Bandar Abbas, Iran. Journal of the Marine Biological Association of the UK, 90, 711-718. https://dx.doi.org/10.1017/S0025315409991056

Seurat, L.G. (1929). Observations sur les limites, les faciès et les associations animales de l'étage intercotidal de la petite Syrte (Golfe de Gabès). Bulletin de l'Institut National des Sciences et Technologies de la Mer de Salammbô, 3, 1-71.

Sexton, J.P., McIntyre, P.J., Angert, A.L., \& Rice, K.J. (2009). Evolution and ecology of species range limits. Annual Review of Ecology, Evolution, and Systematics, 40, 415436.

https://dx.doi.org/10.1146/annurev.ecolsys.110308.12 0317

Tlig-Zouari S. (1993). Contribution à l'étude écobiologique de deux espèces de mollusques lamellibranches Pinctada radiata (Leach 1814) et Pinna nobilis (Linné 1758) des îles Kerkennah. PhD Thesis, University of Tunis, 215 pp.

Tlig-Zouari S., Rabahoui L., Irathni I. \& Ben Hassine O.K. (2009). Distribution, habitat and population densities of the invasive species Pinctata radiata (Mollusca: Bivalvia) along the Northern and Eastern coasts of Tunisia. Cahiers de Biologie Marine, 50, 131-142.

https://dx.doi.org/10.21411/CBM.A.32D42B84

Yassien, M.H. (1998). Biological and ecological studies on the pearl oyster, Pinctada radiata (Mollusca, Lamellibranchia) from the Red Sea, with special reference to its tolerance to water pollution. PhD Thesis, Faculty of Science, Ain Shams University, Egypt. 191 pp.

Yassien, M.H., Abd EL-Razek, F.A., \& Kilada. R. (2000). Growth estimates of the Pearl Oyster, Pinctada radiata, from the eastern Mediterranean. Egyptian Journal of Aquatic Biology and Fisheries, 4, 105-118.

Yoshino, K., Katano, T., Hayami, Y., Hamada, T., \& Kobayashi, G. (2013). Morphological variation of pallial organs at sites of differing turbidity: a case study of an arcid bivalve. Journal of the Marine Biological Association of the UK, 93, 1009-1015.

https://dx.doi.org/10.1017/S0025315412000185

Zeinalipour, M., Hasanzadeh Kiabi, B., Reza Shokri, M., \& Ashja Ardalan, A. (2014). Population dynamic and distribution of Barbatia decussata (Bivalvia: Arcidae) on rocky intertidal shores in the northern Persian Gulf (Iran). Tropical Zoology, 27(3), 73-87. https://dx.doi.org/10.1080/03946975.2014.944381

Zenetos, A., Gofas, S., Verlaque, M., Inar, M.E., Garcia Raso, J.E., Bianchi, C.N., Morri, C., Azzurro, E., Bilecenoglu, M., \& Froglia, C. (2010). Alien species in the Mediterranean Sea by 2010. A contribution to the application of European Union's Marine Strategy Framework Directive (MSFD). Part I. Spatial distribution. Mediterranean Marine Science, 11(2), 381-493.

http://dx.doi.org/10.12681/mms.87 